\title{
Impact of School-Based Interventions on Children's Healthful Nutritional Outcomes (2009-2013): Implications for Future Research
}

\author{
Paloma Rohlfs Domínguez
}

\author{
Department of Psychology and Anthropology, Faculty of Nursing and Ocuppational Therapy, University of \\ Extremadura, Cáceres, Spain
}

\begin{abstract}
Objective: The objective was to review the literature on school-based interventions during compulsory education (published in 2009-2013) that may be effective in increasing healthful nutritional outcomes in children. Specific strategies and their limitations will be identified.

Methods: A qualitative systematic analysis of seventeen school-based interventions applied to six-eleven year-old children, and published in peer-reviewed journals from 2009-2013 was carried out.

Results: These studies taken as a whole used a variety of fourteen strategies, such as provision of nutritional and gardening education; repeated exposure to vegetables (V); peer and adult modelling; chefs going into schools to teach healthy nutritional issues. These studies showed four types of limitations: limitations derived from the experimental designs and experimental procedures used and limitations affecting participant samples and data collection. Fifteen recommendations for overcoming the targeted research limitations were identified, such as applying the intervention during longer time intervals; examining the effectiveness of these interventions in different ethnicities and socioeconomic groups; including larger participant samples; using randomized designs. Finally, six new working hypotheses to guide future studies are proposed here. For example, a small number of $V$ offered might lead to insufficient opportunities to learn to like the flavour of V; schools' previous experience with these interventions might distort children's postintervention data related to their nutritional outcomes; providing children with nutritional and gardening education might increase their fruit $(F)$ selection, consumption and preferences and application of evaluative conditioning under more appropriate experimental conditions might increase child $\mathrm{V}$ consumption.

Conclusion: seventeen school-based interventions were included. These studies taken as a whole used a variety of strategies (fourteen), and showed four types of limitations. Fifteen recommendations for overcoming the targeted research limitations as well as six new hypotheses are proposed here. Future research in this field should focus on overcoming its research limitations, such as the ones highlighted here, and building new working hypotheses, such as those proposed here.
\end{abstract}

Keywords: Children, vegetables, fruits, consumption, schools.

\section{INTRODUCTION}

It is well known that early vegetable consumption -a healthy nutritional habit - counteracts childhood obesity, one of the most worrying public health problems throughout the world [1], as well as health problems in adulthood, such as obesity [2], hypertension, heart disease and cancer [3-5]. Children's intake rates remain, however, lower than national recommendations $[6,7]$, an average of 3 portions daily in Europe [7].

Children's patterns of food intake are also linked to their food preferences $[8,9]$ and their liking for specific foods [10], those early preferences lasting until adolescence and even young adulthood [11-13]. However, these early likings and preferences for foods are not immutable. Indeed, early experiences (i.e. during childhood) with edibles, including $\vee$, may induce

*Address correspondence to this author at the Department of Psychology and Anthropology, Faculty of Nursing and Ocuppational Therapy, University of Extremadura Avda. de la Universidad s/n, 10003 Cáceres, Spain; Tel: 927257000/Ext. 51241; E-mail: prohlfsdomnguez@yahoo.es and modify the establishment of stable food preference patterns and nutritional habits [14-18].

In Spain, primary education is compulsory for 6-12year-old children [19], while children from birth until the age of 6 years may voluntarily attend schools specially designed for their early age (kindergarten) [20]. It has been estimated that at least $20 \%$ of the children who attend a Spanish school (either private or public) have lunch (the main meal in Spain) each day in school during the 8-9 month academic period [21]. Other countries, such as the United Kingdom, Ireland, Argentina, Sweden, and United States of America also provide children with food in the school dining rooms [22-26]. Therefore, the fact that many children receive at least one meal at school is not only exclusive to Spain, but is a worldwide social phenomenon.

Because the school is an environment that provides many children with edibles, it may thereby shape childhood food preferences and eating habits [27-30].

Based on this brief overview, the following questions were considered: Which school-based 
interventions during the compulsory education period may be effective in increasing healthful nutritional outcomes in children? Nutritional outcomes are considered here as being healthy when the involved edibles were fruits $(F), V$, or $F$ and $V(F V)$. What limitations are found in these school-based interventions? How can these limitations be overcome in future research efforts to develop viable strategies for promoting healthy nutritional outcomes in children? In an attempt to answer these questions, pertinent research on school-based interventions published from 2009 to 2013 is reviewed. This work begins with a description of the criteria for considering studies and the corresponding search strategy, along with a synthesized comparison of the study findings. This is followed by a discussion of the implications of the results of these studies for future research in this field (recommendations for overcoming identified research limitations and new working hypotheses).

\section{METHODOLOGY}

\section{Criteria for Considering Studies}

A literature search of published studies on food consumption by children in school settings was carried out. More specifically, studies were included if they dealt with several particular healthy nutritional outcomes (Table 1). Moreover, studies were included if they were school-based, that is, if they were clearly carried out, at least partially, in any physical space of the target school buildings, such as classrooms, dining halls or cafeterias. The focus of the present work concerns 6-11 year-old children exclusively, an agerange when children are typically required to attend compulsory education at schools worldwide [19]. Younger children, in contrast, may attend school in many European countries, such as Spain [20] and Germany [31] as well as the USA [32], but in a voluntary way, depending on parents' wishes. Children older than 11 years are approaching adolescence [33, 34], and the focus is childhood. A wide range of study designs were included in order to ensure the inclusion of a vast spectrum of intervention strategies that improved children's healthy nutritional outcomes. Indeed, randomized and non-randomized, controlled and non-controlled trials and school-based interventions with and without follow-up evaluations were included. Furthermore, this work includes only those studies that were published in peer-reviewed journals between 2009 and August 2013. Previous related work [35] focused on similar school-based interventions published between 2000 and 2008 .
Indeed, this work aims to complement that earlier research. Studies were excluded if they were not school-based, if they targeted pupils showing medical specific problems and/or children older or younger than the above-mentioned targeted age range (Table 2).

Table 1: Healthy Nutritional Outcomes Included

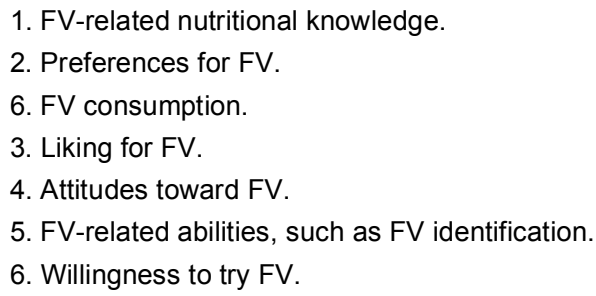

Table 2: Inclusion and Exclusion Criteria

Inclusion criteria
1. Intervention: school-based.
2. Targeted edibles: F, V or FV.
3. Setting: compulsory education (6-11 year old).
4. Outcomes: Table 1.
5. Years of publication: from 2009 to August 2013.
6. Study design: randomized and non-randomized, controlled
and non-controlled trials and school-based interventions with
and without follow-up examinations.
Exclusion criteria
1. Not school-based intervention.
2. Not focused on FV.
3. Targeted children having a specific medical problem.
4. Children aged outside the age range 6-11 years.

\section{Search Strategy}

The search strategy involved Academic Search Complete, PubMed and ScienceDirect as the databases to identify published studies. Only studies that met all of the following criteria were included: population (6-11 year-old and thus school-aged children); interventions (school-based interventions, school-based nutrition programs, or school-based nutritional interventions); school food environment (school lunches, school meals, canteen, cafeteria, or food services); targeted edibles (FV); nutritional outcomes.

\section{RESULTS}

\section{Synthesized Comparison of Study Findings}

A total of seventeen studies that met the inclusion criteria were included. A systematic analysis and descriptive review of these studies, rather than a 
Table 3: Characteristics of the Studies Included in this Review

\begin{tabular}{|c|c|c|c|c|}
\hline Reference & Objectives & Explicit Hypothesis & $\begin{array}{l}\text { Study Design, } \\
\text { Follow-up }\end{array}$ & $\begin{array}{l}\text { Participants (Groups, Age } \\
\text { and sample size) }\end{array}$ \\
\hline 1. $[36]$ & $\begin{array}{l}\text { To increase children's } \\
\text { knowledge of healthy nutritional } \\
\text { habits; psychosocial variables. } \\
\text { Associated with eating FV. And } \\
\text { preferences for FV. }\end{array}$ & $\begin{array}{l}\text { Children of the intervention } \\
\text { group would achieve these } \\
\text { objectives in a more extent } \\
\text { than the control group. }\end{array}$ & $\begin{array}{l}\text { Randomized trial. } \\
\text { Controlled trial. } \\
\text { No follow- up. }\end{array}$ & $\begin{array}{l}\text { One intervention group. } \\
\text { One control group. } \\
9-11 \text { years } \\
n=255 .\end{array}$ \\
\hline 3. [38] & $\begin{array}{l}\text { To examine the impact of a } \\
\text { school garden on children's FV } \\
\text { knowledge, preference and } \\
\text { consumption. }\end{array}$ & $\begin{array}{l}\text { Children of the intervention } \\
\text { group would be more likely to } \\
\text { choose and eat vegetables } \\
\text { during the lunch time after the } \\
\text { intervention, in comparison } \\
\text { with both control groups. }\end{array}$ & $\begin{array}{l}\text { Non-randomized } \\
\text { trial. } \\
\text { Controlled trial. } \\
\text { No follow- up. }\end{array}$ & $\begin{array}{l}\text { One intervention group: } \\
\text { Nutrition education and } \\
\text { gardening. } \\
\text { Two control groups: } \\
\text { 1) Only nutrition education. } \\
\text { 2) No intervention. } \\
7-8 \text { years. } \\
n=115 \text {. }\end{array}$ \\
\hline 4. [39] & $\begin{array}{l}\text { To examine if repeated tastings } \\
\text { of vegetables would increase } \\
\text { children's liking for vegetables. } \\
\text { To determine the number of } \\
\text { tastings required for changing } \\
\text { children's disliking for } \\
\text { vegetables to liking them or } \\
\text { liking them a lot. }\end{array}$ & $\begin{array}{l}\text { Repeated exposure to } \\
\text { vegetables would increase } \\
\text { children's liking for vegetables. }\end{array}$ & $\begin{array}{l}\text { Non-randomized } \\
\text { trial. } \\
\text { Non-controlled trial. } \\
\text { No follow- up. }\end{array}$ & $\begin{array}{l}\text { Three intervention groups: } \\
\text { 1) Children who did not like } \\
\text { vegetables prior to the } \\
\text { intervention. } \\
\text { 2) Children who liked them } \\
\text { prior to the intervention. } \\
\text { 3) Children who liked them a } \\
\text { lot prior to the intervention. } \\
\text { No control group. } \\
9-11 \text { years. } \\
n=360 \text {. }\end{array}$ \\
\hline 6. [41] & $\begin{array}{l}\text { To improve the school } \\
\text { environment and child nutrition } \\
\text { by youth partnerships. }\end{array}$ & $\begin{array}{l}\text { Child peer leaders' implication } \\
\text { in the whole intervention } \\
\text { process (planning, } \\
\text { implementation and evaluation } \\
\text { of results) would improve their } \\
\text { dietary intake, in comparison to } \\
\text { the control group. }\end{array}$ & $\begin{array}{l}\text { Non-randomized } \\
\text { trial. } \\
\text { Controlled trial. } \\
\text { No follow- up. }\end{array}$ & $\begin{array}{l}\text { Two intervention groups, which } \\
\text { received a nutritional education } \\
\text { program by the researchers } \\
\text { and peers: } \\
\text { 1) These peers implemented a } \\
\text { FV snack stand in classrooms. } \\
\text { 2) These peers implemented } \\
\text { the access to the teachers' } \\
\text { salad bar. } \\
\text { One control group, which } \\
\text { received only the standard } \\
\text { classroom nutrition education } \\
\text { without peers' implication. } \\
9-10 \text { years. } \\
n=104 \text {. }\end{array}$ \\
\hline
\end{tabular}


(Table 3). Continued

\begin{tabular}{|c|c|c|c|c|}
\hline Reference & Objectives & Explicit Hypothesis & $\begin{array}{l}\text { Study Design, } \\
\text { Follow-up }\end{array}$ & $\begin{array}{l}\text { Participants (Groups, Age } \\
\text { and sample size) }\end{array}$ \\
\hline 7. [42] & $\begin{array}{l}\text { To increase children's liking for } \\
\text { FV by offering them repeated } \\
\text { opportunities to taste these } \\
\text { items. }\end{array}$ & & $\begin{array}{l}\text { Non-randomized } \\
\text { trial. } \\
\text { Non- controlled trial. } \\
\text { Follow-up: at } 4^{\text {th }} \text { and } \\
10^{\text {th }} \text { post } \\
\text { intervention months. }\end{array}$ & $\begin{array}{l}\text { Two intervention groups: } \\
\text { 1) Children who disliked the } \\
\text { targeted FV before the } \\
\text { intervention. } \\
\text { 2) Children who liked the } \\
\text { targeted FV before the } \\
\text { intervention. } \\
\text { No control group. } \\
6-9 \text { years. } \\
n=379 .\end{array}$ \\
\hline 8. [43] & $\begin{array}{l}\text { To examine the impact of a } \\
\text { multi-component, theory-based } \\
\text { intervention in children's FV } \\
\text { consumption, preferences, } \\
\text { knowledge and body mass } \\
\text { index. }\end{array}$ & $\begin{array}{l}\text { Children exposed to the } \\
\text { intervention would show an } \\
\text { increased FV knowledge, } \\
\text { preferences and lunch time } \\
\text { consumption as well as lower } \\
\text { BMls, in comparison to the } \\
\text { control group. }\end{array}$ & $\begin{array}{l}\text { Randomized trial. } \\
\text { Controlled trial. } \\
\text { Follow-up: at the } \\
\text { first-3th post- } \\
\text { intervention years. }\end{array}$ & $\begin{array}{l}\text { One intervention group. These } \\
\text { children were exposed to the } \\
\text { intervention. } \\
\text { One control group. These } \\
\text { children were not exposed to } \\
\text { the intervention. } \\
\text { Mean age: } 6.2 \text { years. } \\
n=149 \text {. }\end{array}$ \\
\hline 9. [44] & $\begin{array}{l}\text { To examine the effects of } \\
\text { exposure to vegetables of } \\
\text { different liking levels on } \\
\text { children's liking for and intake of } \\
\text { vegetables. }\end{array}$ & $\begin{array}{l}\text { 1) Exposure to vegetables } \\
\text { would increase children's } \\
\text { preferences for and intake of } \\
\text { vegetables. } \\
\text { 2) Changes in liking, derived } \\
\text { from exposure to vegetables, } \\
\text { would be transferred to similar } \\
\text { non-exposed vegetables. } \\
\text { 3) Children would show } \\
\text { increases and decreases in } \\
\text { liking for and intake of neutrally } \\
\text { liked vegetables paired with } \\
\text { liked and non-liked vegetables, } \\
\text { respectively. }\end{array}$ & $\begin{array}{l}\text { Randomized trial. } \\
\text { Controlled trial. } \\
\text { Follow-up: at the } \\
\text { first-post- } \\
\text { intervention day. }\end{array}$ & $\begin{array}{l}\text { Three intervention groups: } \\
\text { 1) These children received a } \\
\text { mixture of a neutrally liked } \\
\text { vegetable and a liked } \\
\text { vegetable. } \\
\text { 2) These children received only } \\
\text { a neutrally liked vegetable. } \\
\text { 3) These children received a } \\
\text { mixture of a neutrally liked } \\
\text { vegetable and a disliked } \\
\text { vegetable. } \\
\text { One control group. These } \\
\text { children did not receive any } \\
\text { exposure intervention. } \\
9-11 \text { years. } \\
n=345 \text {. }\end{array}$ \\
\hline 10. $[45]$ & $\begin{array}{l}\text { To evaluate the effects of a } \\
\text { multi-component nutrition } \\
\text { education program on children's } \\
\text { knowledge, attitudes and } \\
\text { behaviours related to } \\
\text { consumption of FV. }\end{array}$ & & $\begin{array}{l}\text { Non-randomized } \\
\text { trial. } \\
\text { Controlled trial. } \\
\text { No follow- up. }\end{array}$ & $\begin{array}{l}\text { Two intervention groups: } \\
\text { 1) Children received an } \\
\text { educational program. Teachers } \\
\text { and parents were involved in } \\
\text { the intervention as role models } \\
\text { for behaviour change. } \\
\text { 2) Children received an } \\
\text { educational program, but } \\
\text { teachers and parents were not } \\
\text { involved in the intervention. } \\
\text { One control group. These } \\
\text { children did not receive the } \\
\text { educational program. } \\
\text { 8-11 years. } \\
n=399 \text {. }\end{array}$ \\
\hline 11. [46] & $\begin{array}{l}\text { To examine the impact of an } \\
\text { educational program together } \\
\text { with repeated food exposures } \\
\text { on children's ability to identify } \\
\text { FV and willingness to try FV. }\end{array}$ & $\begin{array}{l}\text { Children who received the } \\
\text { nutritional education program } \\
\text { together with food exposures } \\
\text { would be better at identifying } \\
\text { and more willing to try FV, } \\
\text { compared to other children. }\end{array}$ & $\begin{array}{l}\text { Non-randomized } \\
\text { trial. } \\
\text { Non-controlled trial. } \\
\text { No follow- up. }\end{array}$ & $\begin{array}{l}\text { Two intervention groups: } \\
\text { 1) Children who received the } \\
\text { educational program plus } \\
\text { repeated FV exposures. } \\
\text { 2) Children who only received } \\
\text { the educational program. } \\
\text { No control group. } \\
5-6 \text { years. } \\
n=88 \text {. }\end{array}$ \\
\hline
\end{tabular}


(Table 3). Continued.

\begin{tabular}{|c|c|c|c|c|}
\hline Reference & Objectives & Explicit Hypothesis & $\begin{array}{l}\text { Study Design, } \\
\text { Follow-up }\end{array}$ & $\begin{array}{l}\text { Participants (Groups, Age } \\
\text { and sample size) }\end{array}$ \\
\hline 12. [47] & $\begin{array}{l}\text { To examine the impact of the so } \\
\text { called CHANGE intervention on } \\
\text { children's diet quality, thus } \\
\text { preventing children's unhealthy } \\
\text { weight gain. }\end{array}$ & $\begin{array}{l}\text { Children exposed to the } \\
\text { intervention would improve } \\
\text { their diet quality, in comparison } \\
\text { with other children. }\end{array}$ & $\begin{array}{l}\text { Randomized trial. } \\
\text { Controlled trial. } \\
\text { No follow- up. }\end{array}$ & $\begin{array}{l}\text { One intervention group. These } \\
\text { children were exposed to the } \\
\text { intervention. } \\
\text { One control group. These } \\
\text { children were not exposed to } \\
\text { the intervention. } \\
6-12 \text { years. } \\
n=432 \text {. }\end{array}$ \\
\hline 13. $[48]$ & $\begin{array}{l}\text { To examine the effects of chefs } \\
\text { going into schools to teach } \\
\text { children to prepare and taste } \\
\text { healthy food on children's food } \\
\text { preparation and consumption as } \\
\text { well as cooking confidence. }\end{array}$ & & $\begin{array}{l}\text { Randomized trial. } \\
\text { Controlled trial. } \\
\text { No follow- up. }\end{array}$ & $\begin{array}{l}\text { One intervention group. These } \\
\text { children were exposed to the } \\
\text { intervention. } \\
\text { One control group. These } \\
\text { children were not exposed to } \\
\text { the intervention. } \\
9-11 \text { years. } \\
n=169 \text {. }\end{array}$ \\
\hline 14. [49] & $\begin{array}{l}\text { To examine the effectiveness of } \\
\text { the choice strategy on children's } \\
\text { vegetable consumption. }\end{array}$ & $\begin{array}{l}\text { Children provided with choice } \\
\text { would consume more } \\
\text { vegetables than children not } \\
\text { provided with choice. } \\
\text { Children having choice } \\
\text { availability continuously during } \\
\text { the meal would show a higher } \\
\text { vegetable intake than those } \\
\text { who had choice availability } \\
\text { only once. }\end{array}$ & $\begin{array}{l}\text { Randomized trial. } \\
\text { Controlled trial. } \\
\text { No follow- up. }\end{array}$ & $\begin{array}{l}\text { Two intervention groups: } \\
\text { 1) Children chose the } \\
\text { vegetable to ingest once } \\
\text { before the meal. } \\
\text { 2) Children chose the } \\
\text { vegetable during the meal, } \\
\text { whenever they made a bite. } \\
\text { One control group. These } \\
\text { children could not choose the } \\
\text { vegetable. } \\
\text { 4-6 years. } \\
n=150 .\end{array}$ \\
\hline 15. [50] & $\begin{array}{l}\text { To examine the effectiveness of } \\
\text { adult modelling (the teacher } \\
\text { being the exposure model) on } \\
\text { children's fruit intake. }\end{array}$ & & $\begin{array}{l}\text { Randomized trial. } \\
\text { Controlled trial. } \\
\text { Follow-up: at the } \\
\text { first post- } \\
\text { intervention year. }\end{array}$ & $\begin{array}{l}\text { Two intervention groups: } \\
\text { 1) Children were exposed only } \\
\text { to an educational program. } \\
\text { 2) Children were exposed only } \\
\text { to adult modelling. } \\
\text { One control group. These } \\
\text { children were not exposed to } \\
\text { any intervention. } \\
9 \text { years. } \\
n=184 \text {. }\end{array}$ \\
\hline 16. [51] & $\begin{array}{l}\text { To examine the effectiveness of } \\
\text { integrating animal cartoon } \\
\text { characters into a } \\
\text { comprehensive nutritional } \\
\text { education program in children's } \\
\text { FV consumption and physical } \\
\text { activity. }\end{array}$ & & $\begin{array}{l}\text { Non-randomized } \\
\text { trial. } \\
\text { Non-controlled trial. } \\
\text { No follow-up result } \\
\text { assessment. }\end{array}$ & $\begin{array}{l}\text { One intervention group. These } \\
\text { children were exposed to the } \\
\text { intervention. } \\
8 \text { - } 11 \text { years. } \\
n=4,128 .\end{array}$ \\
\hline 17. [52] & $\begin{array}{l}\text { To examine the effectiveness of } \\
\text { peer modelling combined with } \\
\text { rewarding in children's FV. }\end{array}$ & & $\begin{array}{l}\text { Non-randomized } \\
\text { trial. } \\
\text { Non-controlled trial. } \\
\text { No follow-up result } \\
\text { assessment. }\end{array}$ & $\begin{array}{l}\text { Three intervention groups: } \\
\text { 1) Children who consumed no } \\
\text { fruit at pre-intervention base } \\
\text { line. } \\
\text { 2) Children who consumed no } \\
\text { vegetable at pre-intervention } \\
\text { base line. } \\
\text { 3) Children who consumed FV } \\
\text { at pre-intervention base line. } \\
\text { All these children were } \\
\text { exposed to the intervention. } \\
\text { No control group. } \\
6-11 \text { years. } \\
n=253 \text {. }\end{array}$ \\
\hline
\end{tabular}


(Table 3). Continued

\begin{tabular}{|c|c|c|c|}
\hline $\begin{array}{l}\text { Country, City, School physical } \\
\text { space }\end{array}$ & Procedures & Results (they are significant) & Limitations \\
\hline $\begin{array}{l}\text { USA; Southeast Louisiana. } \\
\text { Classrooms of different public } \\
\text { schools. }\end{array}$ & $\begin{array}{l}\text { Provision of nutritional } \\
\text { knowledge aimed to learn } \\
\text { the physiology of } \\
\text { digestion and the } \\
\text { importance of consuming } \\
\text { healthy foods, such as } \\
\text { FV. } \\
\text { Modification of children's } \\
\text { social environment } \\
\text { leading to encourage to } \\
\text { consume FV. }\end{array}$ & $\begin{array}{l}\text { In comparison to control children, } \\
\text { children of the intervention group } \\
\text { showed an increase in their } \\
\text { healthy nutritional knowledge, } \\
\text { and the psychosocial variables } \\
\text { associated with eating FV were } \\
\text { improved. } \\
\text { However, their preferences for } \\
\text { FV did not change. }\end{array}$ & $\begin{array}{l}\text { The program had a relatively short, 12- } \\
\text { week duration. This may be insufficient } \\
\text { time for changing children's food } \\
\text { preferences. } \\
\text { Follow-up assessment of the program } \\
\text { was not examined, so long-term } \\
\text { effects of the program are unknown. } \\
\text { The majority of children were black } \\
\text { and resided in low-income households, } \\
\text { so results cannot be generalized to } \\
\text { other socioeconomic groups and } \\
\text { ethnicities. }\end{array}$ \\
\hline $\begin{array}{l}\text { USA; Rural Kentucky. } \\
\text { One school cafeteria. }\end{array}$ & $\begin{array}{l}\text { The kitchen staff was } \\
\text { asked to serve whole and } \\
\text { sliced apples and oranges } \\
\text { in the usual manner. } \\
\text { On day } 1 \text {, children could } \\
\text { choose the sliced fruits } \\
\text { among other food options. } \\
\text { On day } 2 \text {, children could } \\
\text { choose the whole fruits } \\
\text { among other food options. }\end{array}$ & $\begin{array}{l}\text { Slicing fruit encouraged children's } \\
\text { fruit selection and consumption, } \\
\text { only in the case of oranges. } \\
\text { The greatest slicing effect was } \\
\text { observed among the younger } \\
\text { children. }\end{array}$ & $\begin{array}{l}\text { There were no independent subject } \\
\text { and food samples, so different factors } \\
\text { from slicing may have (also) influenced } \\
\text { the results. } \\
\text { Results cannot be generalized to other } \\
\text { populations. }\end{array}$ \\
\hline $\begin{array}{l}\text { USA; Southeastern. } \\
\text { Classrooms and garden of one } \\
\text { school. }\end{array}$ & $\begin{array}{l}\text { Provision of nutritional } \\
\text { and gardening education. }\end{array}$ & $\begin{array}{l}\text { The first hypothesis was fulfilled. } \\
\text { However, the intervention group } \\
\text { and the first control group } \\
\text { showed, with no significant } \\
\text { differences between both groups, } \\
\text { greater improvements in nutrition } \\
\text { knowledge than the second } \\
\text { control group. } \\
\text { There was no impact on } \\
\text { children's fruit-related knowledge, } \\
\text { preferences and consumption. }\end{array}$ & $\begin{array}{l}\text { The study did not use a randomized } \\
\text { design. } \\
\text { The sample size was not as large as } \\
\text { desirable. } \\
\text { The study did not include a follow-up } \\
\text { assessment to determine long-term } \\
\text { results. } \\
\text { Participants were predominantly white, } \\
\text { second-grade population, and results } \\
\text { should not be generalized to other } \\
\text { populations. }\end{array}$ \\
\hline $\begin{array}{l}\text { USA; South-eastern Louisiana. } \\
\text { The cafeterias and classrooms } \\
\text { of four low-income public } \\
\text { schools. }\end{array}$ & $\begin{array}{l}\text { Provision of a vegetable } \\
\text { tasting program combined } \\
\text { with a nutritional } \\
\text { education program. }\end{array}$ & $\begin{array}{l}\text { Liking for the majority of the } \\
\text { targeted vegetables was } \\
\text { increased in the first group of } \\
\text { children. } \\
\text { No changes in liking for the } \\
\text { vegetables were observed in the } \\
\text { other two groups. }\end{array}$ & $\begin{array}{l}\text { Children were } 9-11 \text { year old and } \\
\text { attending low-income schools of } \\
\text { South-eastern Louisiana. The } 80 \% \text { of } \\
\text { them were black, so results should not } \\
\text { be generalized to other populations. } \\
\text { Questionnaires were used to collect } \\
\text { information on children, and social } \\
\text { desirability might have biased the } \\
\text { results. } \\
\text { There was no control group. } \\
\text { A random design was not used. } \\
\text { Lower rate of participation of children } \\
\text { of the first group. }\end{array}$ \\
\hline $\begin{array}{l}\text { USA; California. } \\
\text { Classrooms; dining halls and } \\
\text { gardens of different schools. }\end{array}$ & $\begin{array}{l}\text { A combined provision of } \\
\text { nutritional lessons, } \\
\text { cooking and garden } \\
\text { classes, as well as } \\
\text { exposure to FV. }\end{array}$ & $\begin{array}{l}\text { There was no difference in } \\
\text { nutritional knowledge nor } \\
\text { attitudes toward healthy eating } \\
\text { behaviours by intervention } \\
\text { degree. } \\
\text { The most increases in } \\
\text { preferences for FV were found in } \\
\text { the children of the high-degree } \\
\text { intervention development. These } \\
\text { children also showed significant } \\
\text { increases in FV consumption, but } \\
\text { only at the school, while children } \\
\text { of the low-degree intervention } \\
\text { development showed a decrease } \\
\text { in this variable. }\end{array}$ & $\begin{array}{l}\text { Nor control nor random design was } \\
\text { used. } \\
\text { Some schools had advantage over } \\
\text { other schools in implementing the } \\
\text { intervention because of their greater } \\
\text { experience in this program. } \\
\text { The youngest children had difficulties } \\
\text { in providing researchers the } \\
\text { information required. } \\
\text { Some of the information was collected } \\
\text { only in working days, weekends having } \\
\text { been omitted. } \\
\text { The intervention was not applied at } \\
\text { home. }\end{array}$ \\
\hline
\end{tabular}


(Table 3). Continued.

\begin{tabular}{|c|c|c|c|}
\hline $\begin{array}{l}\text { Country, City, School physical } \\
\text { space }\end{array}$ & Procedures & Results (they are significant) & Limitations \\
\hline $\begin{array}{l}\text { USA; rural East Tennesee. } \\
\text { Classrooms of different schools. }\end{array}$ & $\begin{array}{l}\text { Provision of taste-related } \\
\text { FV experiences by child } \\
\text { peers and/or adults. }\end{array}$ & $\begin{array}{l}\text { The first intervention group } \\
\text { showed an increased fruit } \\
\text { consumption. } \\
\text { The second intervention group } \\
\text { showed a reduced energy intake. }\end{array}$ & $\begin{array}{l}\text { The second intervention group showed } \\
\text { a reduced fruit and vegetable intake, } \\
\text { due to problems related to the } \\
\text { measurement of dietary consumption. }\end{array}$ \\
\hline $\begin{array}{l}\text { USA; Southeast Louisiana. } \\
\text { Cafeteria of low-income schools. }\end{array}$ & $\begin{array}{l}\text { Repeated exposure to FV } \\
\text { during } 8 \text { weeks. }\end{array}$ & $\begin{array}{l}\text { Children of the first group showed } \\
\text { an improvement of their liking for } \\
\text { FV after the intervention and } \\
\text { maintained this improvement at } \\
\text { both follow-up assessments. } \\
\text { There were some gender and } \\
\text { grade differences at each } \\
\text { assessment time. } \\
\text { The number of exposures } \\
\text { required for observing these } \\
\text { increases in liking for FV were } \\
\text { two and three, respectively. } \\
\text { Children of the second group } \\
\text { maintained their liking status at } \\
\text { each assessment time, and there } \\
\text { were no gender or grade } \\
\text { differences. }\end{array}$ & $\begin{array}{l}\text { Participants were first, 2th and 3th } \\
\text { graders from low-income schools, so } \\
\text { results should not be generalized to } \\
\text { other populations. } \\
\text { Social desirability could have } \\
\text { influenced children's responses. } \\
\text { There was no control group. }\end{array}$ \\
\hline $\begin{array}{l}\text { USA; North-eastern. } \\
\text { Classrooms, lunchrooms of } \\
\text { different schools and children's } \\
\text { homes. }\end{array}$ & $\begin{array}{l}\text { Provision of the following } \\
\text { components for promoting } \\
\text { FV consumption: } \\
\text { 1) Loudspeaker } \\
\text { announcements. } \\
\text { 2) Instructional material } \\
\text { (DVD). } \\
\text { 3) Contingent rewarding } \\
\text { on a bite of FV. } \\
\text { 4) Take-home activity } \\
\text { books. }\end{array}$ & $\begin{array}{l}\text { In comparison to the control } \\
\text { group, the intervention group } \\
\text { increased the FV consumption, } \\
\text { although this effect declined } \\
\text { across time. } \\
\text { Preferences for FV and BMls did } \\
\text { not change between groups. } \\
\text { There were persistent increases } \\
\text { on children's FV knowledge. }\end{array}$ & $\begin{array}{l}\text { The sample size was not as large as } \\
\text { desirable, which may affect results' } \\
\text { generalization. }\end{array}$ \\
\hline $\begin{array}{l}\text { Denmark; Copenhagen. } \\
\text { Classrooms. }\end{array}$ & $\begin{array}{l}\text { Repeated exposure to } \\
\text { vegetables in the context } \\
\text { of an evaluative } \\
\text { conditioning. }\end{array}$ & $\begin{array}{l}\text { In comparison to the control } \\
\text { group, liking for most vegetables } \\
\text { decreased after the intervention, } \\
\text { but tended to recover somewhat } \\
\text { during the follow-up. } \\
\text { Vegetable intake decreased after } \\
\text { the intervention. } \\
\text { Intake quantity varied across the } \\
\text { type of vegetable servings. } \\
\text { Indeed, children consumed more } \\
\text { of neutrally liked vegetables } \\
\text { when these items were paired } \\
\text { with a liked vegetable than when } \\
\text { served alone or together with a } \\
\text { disliked vegetable. }\end{array}$ & $\begin{array}{l}\text { Most of the children were Caucasian } \\
\text { and middle class, so results should not } \\
\text { be generalized to other populations. } \\
\text { All classes received similar, but } \\
\text { alternating serving orders of } \\
\text { vegetables at liking test days, thus } \\
\text { leading to confounding between } \\
\text { serving order and intervention group. } \\
\text { There could have been peer influences } \\
\text { affecting the data. } \\
\text { There could have been some } \\
\text { overestimations of the intake data, in } \\
\text { the case of children who dropped their } \\
\text { vegetables on the floor. }\end{array}$ \\
\hline $\begin{array}{l}\text { USA; Los Angeles. } \\
\text { Classrooms. }\end{array}$ & $\begin{array}{l}\text { Adult modelling. } \\
\text { Nutrition education } \\
\text { sessions. } \\
\text { Interactive activities. }\end{array}$ & $\begin{array}{l}\text { Neither of the } 2 \text { intervention } \\
\text { groups showed an increased FV } \\
\text { consumption. } \\
\text { Neither of the } 2 \text { intervention } \\
\text { groups showed an increased } \\
\text { availability of FV at home. } \\
\text { Only children of the first } \\
\text { intervention group showed } \\
\text { increases in knowledge, attitudes } \\
\text { and beliefs toward vegetables. } \\
\text { The parent/teacher influence on } \\
\text { children's FV attitudes increased } \\
\text { only in the first group. }\end{array}$ & $\begin{array}{l}\text { Participant groups represented only a } \\
\text { few of some specific ethnic groups, so } \\
\text { results should not be generalized to } \\
\text { other populations. } \\
\text { The small size of the firs intervention } \\
\text { group was to small to observe changes } \\
\text { in FV consumption. } \\
\text { There was no follow-up result } \\
\text { assessment. } \\
\text { There was no intervention on the } \\
\text { school food environment, this resulting } \\
\text { in no behavioural change in vegetable } \\
\text { consumption. }\end{array}$ \\
\hline
\end{tabular}


(Table 3). Continued.

\begin{tabular}{|c|c|c|c|}
\hline $\begin{array}{l}\text { Country, City, School physical } \\
\text { space }\end{array}$ & Procedures & Results (they are significant) & Limitations \\
\hline $\begin{array}{l}\text { USA; Williamsburg James City. } \\
\text { The classrooms of two different } \\
\text { schools. }\end{array}$ & $\begin{array}{l}\text { An educational program, } \\
\text { which included } \\
\text { interactivities about } \\
\text { healthy eating and } \\
\text { physical activity. } \\
\text { Repeated exposure to FV. }\end{array}$ & $\begin{array}{l}\text { All children were better able to } \\
\text { identify FV. } \\
\text { Only the children of the first } \\
\text { intervention group were more } \\
\text { willing to try FV. } \\
\text { There were no changes in } \\
\text { children's identification abilities or } \\
\text { willingness to try vegetables. }\end{array}$ & $\begin{array}{l}\text { Children may have had insufficient } \\
\text { opportunities to learn to like the flavour } \\
\text { of the vegetables, due to the small } \\
\text { number of vegetables offered. } \\
\text { There was no follow-up result } \\
\text { assessment, so effects of the } \\
\text { intervention over the long-term are } \\
\text { unknown. }\end{array}$ \\
\hline $\begin{array}{l}\text { USA; rural areas of California, } \\
\text { Kentucky, Mississippi and South } \\
\text { Carolina. } \\
\text { Classrooms and cafeterias of } \\
\text { different schools; children's } \\
\text { homes. }\end{array}$ & $\begin{array}{l}\text { Changes in the foods } \\
\text { offered in the cafeteria: } \\
\text { more FV and whole grains } \\
\text { and less added-sugar and } \\
\text { saturated-fat products. } \\
\text { Educational program } \\
\text { based on the social- } \\
\text { cognitive theory. } \\
\text { Parent and community } \\
\text { outreach components. }\end{array}$ & $\begin{array}{l}\text { In comparison to the control } \\
\text { group, children of the intervention } \\
\text { group showed an increased } \\
\text { consumption of vegetables and } \\
\text { combined FV, as well as a trend } \\
\text { to consume more fruits. } \\
\text { They also showed a reduced } \\
\text { average daily dietary glycaemic } \\
\text { index. } \\
\text { There were no differences in } \\
\text { children's consumption of whole } \\
\text { grains. }\end{array}$ & $\begin{array}{l}\text { Results are not generalizable to other } \\
\text { populations. } \\
\text { Many children who agreed to } \\
\text { participate in the study failed to } \\
\text { complete a second survey at the end } \\
\text { of the intervention. }\end{array}$ \\
\hline $\begin{array}{l}\text { England; Est London, West } \\
\text { London, North West England } \\
\text { (near Manchester and Liverpool) } \\
\text { and Midlands. } \\
\text { Classrooms of different schools. }\end{array}$ & $\begin{array}{l}\text { Instructional lessons. } \\
\text { Sensory experiences } \\
\text { focused on taste. } \\
\text { Practical cooking sessions } \\
\text { with a chef. }\end{array}$ & $\begin{array}{l}\text { In comparison to the control } \\
\text { group, the intervention group } \\
\text { showed gains in skills and } \\
\text { confidence to prepare and ask for } \\
\text { the ingredients to be purchased } \\
\text { for use in home. These children } \\
\text { also showed an increased } \\
\text { vegetable consumption. }\end{array}$ & $\begin{array}{l}\text { There was no follow-up result } \\
\text { assessment, so it is not known, } \\
\text { whether the results found are } \\
\text { sustained in the long-term. }\end{array}$ \\
\hline $\begin{array}{l}\text { Spain; Granada. } \\
\text { Dining halls of different schools. }\end{array}$ & $\begin{array}{l}\text { Provision of choice } \\
\text { availability at the lunch } \\
\text { time. }\end{array}$ & $\begin{array}{l}\text { Children of both intervention } \\
\text { groups ate more vegetables than } \\
\text { the control group. } \\
\text { There were no differences } \\
\text { between both choice conditions. }\end{array}$ & $\begin{array}{l}\text { There was no follow-up assessment, } \\
\text { so it is not known, whether the results } \\
\text { found are sustained in the long-term. } \\
\text { Children's motivation (liking or } \\
\text { preference) for the targeted vegetables } \\
\text { during and after the meal was not } \\
\text { measured. } \\
\text { Children's attentional focus during the } \\
\text { meal was neither measured. }\end{array}$ \\
\hline $\begin{array}{l}\text { Greece; Chipre. } \\
\text { Classrooms. }\end{array}$ & $\begin{array}{l}\text { Provision of a nutritional } \\
\text { educational program. } \\
\text { Adult modelling. }\end{array}$ & $\begin{array}{l}\text { In comparison to the control } \\
\text { group, both intervention groups } \\
\text { exhibited a higher fruit intake. } \\
\text { At 1-year follow-up, that increase } \\
\text { remained only for the children of } \\
\text { the 2th intervention group. }\end{array}$ & $\begin{array}{l}\text { The misreported food information: food } \\
\text { record during weekends was omitted. } \\
\text { Parents reported information for their } \\
\text { children, but they may not know } \\
\text { exactly what their children ate outside } \\
\text { the school. } \\
\text { The results were obtained from a } \\
\text { single school district, so results are not } \\
\text { generalizable to other populations. }\end{array}$ \\
\hline $\begin{array}{l}\text { USA; Minessota. } \\
\text { Classrroms and cafeteris. }\end{array}$ & $\begin{array}{l}\text { Children's exposure to } \\
\text { animal cartoon } \\
\text { characters. } \\
\text { Provision of nutritional } \\
\text { lessons. } \\
\text { Addition of FV to the } \\
\text { menus offered in the } \\
\text { cafeterias. }\end{array}$ & $\begin{array}{l}\text { Self-reported consumption of FV } \\
\text { was improved. } \\
\text { The number of sessions attended } \\
\text { and improvements in fruit } \\
\text { consumption was weakly but yet } \\
\text { significantly related. }\end{array}$ & $\begin{array}{l}\text { No control group was used. } \\
\text { The survey used self-reported } \\
\text { dichotomous questions. }\end{array}$ \\
\hline $\begin{array}{l}\text { USA; Northen Utah. } \\
\text { Cafeteria. }\end{array}$ & $\begin{array}{l}\text { Children watched videos } \\
\text { in which heroic peers } \\
\text { were eating } \mathrm{FV} \text {, and } \\
\text { received a reward for } \\
\text { eating } \mathrm{FV} \text {. }\end{array}$ & $\begin{array}{l}\text { Children's FV intake increased } \\
\text { after the intervention. This effect } \\
\text { was more discriminable among } \\
\text { children of the first intervention } \\
\text { group. }\end{array}$ & $\begin{array}{l}\text { No control group was used. } \\
\text { Only one school participated in the } \\
\text { study, which may affect the } \\
\text { generalization of results. } \\
\text { The socioeconomic status or ethnicity } \\
\text { in schools with more cultural diversity } \\
\text { may impact the results. } \\
\text { No follow-up assessment was carried } \\
\text { out to check the stability of results in } \\
\text { the long-term. }\end{array}$ \\
\hline
\end{tabular}


meta-analysis, was conducted because of the marked heterogeneity in the types of school-based interventions carried out. Furthermore, the studies used a wide range of methods and outcomes to assess effects on children's nutritional outcomes. The included studies were analyzed according to the three research questions formulated in the introductory section: which school-based interventions executed during that period may be effective in increasing these healthful nutritional outcomes in children? What limitations do these studies present? How would it be possible to overcome these limitations in future investigations of viable strategies for promoting child healthy nutritional outcomes? (Table 3 ).

\section{DISCUSSION AND IMPLICATIONS FOR FUTURE RESEARCH}

Based on the review of the included studies, the answers to the three questions formulated in the introductory section are presented below, along with several implications for future research.

\section{School-Based Interventions Executed During the Compulsory Education Period that may be Effective in Increasing Healthful Nutritional Outcomes in Children}

School-based interventions focused, at least partially, on providing children with nutritional education programs are effective in increasing healthful nutritional outcomes. Indeed, it has been demonstrated that children provided with nutritional and gardening education are more likely to choose and eat a variety of $V$ (i.e. carrots, broccoli, cabbage and zucchini) during lunch time. This strategy also increases their preferences for these items. Their nutritional knowledge also improves if they are exposed to this combination of strategies, but to the same extent as when children only receive nutritional education [38]. Furthermore, this type of intervention does not impact children's selection, consumption or preferences for $F$, when only one $F$ (i.e. blueberry) is offered [38]. Therefore, these authors recommend that future research should examine the same intervention, but using a variety of $F$. Providing children with nutritional knowledge, such as the physiology of digestion and the need for consuming healthy foods, using a language adapted to their age, together with modification of the social environment by, for instance, encouraging children to participate in school assemblies where the message to consume $\mathrm{FV}$ is delivered, also result in an increase in healthy nutritional knowledge. Improvement of the psychosocial variables associated with eating $\mathrm{FV}$ is also found, but there were no changes in preferences for FV [36]. These authors therefore recommend that future research should identify ways to increase children's tasting and exposure to these healthy foods, in addition to those strategies, in order to change their preferences for FV. Following this research line, at least three studies have obtained positive results. Wang et al. [40] found that provision of nutritional lessons, combined with cooking and gardening classes, as well as exposure to FV, increases children's consumption of and preferences for FV. Nutritional knowledge or attitudes toward healthy eating are not affected by this intervention, however. The authors of this study suggest that the potential advantage of some of the schools over others in the implementation of the intervention (because of previous relevant experience) may have distorted children's post-intervention data related to their knowledge and attitudes toward healthy eating. That is, this previous experience could have resulted in a ceiling effect. Therefore, future school-based interventions should also control this variable. Secondly, a school-based intervention that combined an educational program and repeated exposure to FV improves children's ability to identify FV as well as willingness to try FV [46]. These variables are likely to promote FV consumption in children, a hypothesis that should be tested in the future. Thirdly, exposing children to animal cartoon characters within a comprehensive nutritional education program consisting of the provision of nutritional lessons, plus addition of $\mathrm{FV}$ offered in the school cafeterias, improves children's self-reported FV and F consumption [51].

Other effective school-based interventions are those focused on repeated exposure to FV as the only strategy applied. Repeated exposure increases liking for $\mathrm{V}$ and $\mathrm{FV}$ in children who did not like the targeted items before this repeated taste-related experience [39, 42]. This result was constant across time (four and ten months later) and subject to gender and grade variables [42]. In the case of $F$, fewer exposures -two times- are required for observing an increase in liking for these items, in comparison to the number of exposures required to increase liking for $\mathrm{V}$-three times- [42]. The authors attribute this effect to children's innate liking and rejection for the sweet and bitter tastes of $F$ and $V$, respectively. In contrast, repeated exposure does not change liking for $V$ and $F V$ in children who already liked $V$ before the repeated 
tastings [39, 42]. Therefore, it is suggested that future research should examine whether adding to the targeted $\mathrm{V}$ some sweetener or even a sweet $\mathrm{F}$, that is, using the so-called evaluative conditioning experimental paradigm -within this paradigm, a neutral or even rejected stimulus is paired with an already liked stimulus- (see Gast, Gawronski and De Houwer [53] for a review) might increase children's liking for $\mathrm{V}$ that is already liked (but see Olsen et al. [44] for a different point of view). Indeed, as it is have been pointed out in a previous section, these authors found no increases in liking for or intake of already liked $\mathrm{V}$ motivated by evaluative conditioning. Authors of this study attribute this result, either to children's limited attention focused on the targeted $V$, due to peer influence, or to children's V-related boredom sensation or the large size of $V$ servings. Future research should examine evaluative conditioning related to child $\mathrm{V}$ consumption under more appropriate experimental conditions.

In addition to the strategies that have been discussed so far in this section, there are four more that deserve readers' attention. The first involves manipulation of the food environment at schools. For example, offering sliced $F$ in the cafeteria has been shown to encourage children's $F$ selection and consumption of oranges, especially among younger children, but does not impact consumption of apples [37]. Therefore, future research should develop additional age- and F-specific strategies to encourage child $F$ consumption. Similarly, offering children more FV and whole grains with less added-sugar and saturated-fat products in the school cafeteria has been found to increase children's $V$ and FV consumption while reducing dietary glycaemic index [47]. Furtheremore, providing children with the opportunity to choose the $V$ to ingest once before the meal or whenever they take a bite during the meal has been demonstrated to increase their $V$ intake [49]. The second strategy refers to others' influence. Provision of a FV snack stand in classrooms by peers increased children's $F$ consumption [41]. Furtheremore, peer modeling has been observed to increase children's FV intake [52], and adult modeling also increased children's knowledge, attitudes and beliefs toward FV, although it did not increase their FV consumption nor availability of FV at children's home [45]. Such modelling also increases children's $F$ consumption, with this effect remaining across time (one year later) [50]. The third strategy is associated with the influence of chefs. School programs in which chefs teach children to prepare and taste healthy food has been demonstrated to increase children's $V$ intake as well as their skills and confidence to prepare and ask for the ingredients to be purchased for use at home [48]. Finally, promotion of $\mathrm{FV}$ consumption by means of loudspeaker announcements, instructional material (DVD), contingent rewards, and take-home activity books has been found to increase children's FV consumption, although this effect declines across time (three months later) [43]. This kind of intervention has also demonstrated increases in children's FV knowledge, but does not change their preferences for FV, however [43]. These authors attribute this result to the fact that they did not make the FV more palatable. Therefore, the effectiveness of increased palatability of the FV served in enhancing children's preferences for those food items should be tested in the future.

As can be seen, the effectiveness of a school-based intervention in increasing healthful nutritional outcomes in child population relies on the specific strategy or strategies used. Across the included studies, fourteen strategies have been used (Table 4).

Table 4: Essential Strategies Used by School-Based Interventions Identified

1. Provision of nutritional knowledge combined with modification of children's social environment.

2. Slicing $F$.

3. Provision of nutritional and gardening education.

4. Repeated exposure to $V$

5. Provision of nutritional lessons, combined with cooking and gardening classes, and exposure to FV.

6. Provision of a FV snack stand in classrooms by peers.

7. Peer modelling.

8. Adult modelling.

9. Provision of loudspeaker announcements, instructional material (DVD), contingent rewarding on a bite of FV, and take-home activity books.

10. Provision of an educational program combined with repeated exposure to FV.

11. Offering more FV in the school cafeteria.

12. Chefs going into schools to teach healthy nutritional issues.

13. Provision of the opportunity to choose the $V$ to ingest.

14. Exposure to animal cartoon characters within a comprehensive nutritional education program.

\section{Limitations of these Studies and ways to Overcome them in Future Research}

Limitations of these studies can be placed into four categories.

1. Limitations derived from the experimental designs used. The most common of this type of limitation 
concerns the lack of follow-up assesments to check whether the intervention remains effective in the longterm. This limitation affects the studies by Tuuri, et al. [36], Prelip et al. [45], Schindler et al. [46], Caraher et al. [48], Rohlfs Domínguez et al. [49] and Wengreen et al. [52]. Future research should therefore examine the effectiveness of these interventions in the long-term by adding at least one follow-up assesment at any postintervention month or even year. A second limitation relates to the lack of control groups with which to compare the results of the experimental groups. This limitation is found in the studies by Swanson et al. [37], Lakkakula et al. [39], Leines et al. [51], Wengreen et al. [52], and Wang et al. [40]. These comparisons are essential for ascertaining whether the effectiveness of a school-based intervention may be exclusively attributed to manipulation of the independent variable, in this case, the type of strategy used for improving children's healthy nutritional outcomes. Consequently, a better examination of the efectivenness of these school-based interventions by adding control groups is warranted. The third limitation involves the lack of randomized experimental designs. This limitation exists in the studies by Parmer et al. [38], Lakkakula et al. [39], and Wang et al. [40]. Randomized experimental designs also ensure attribution of the effectiveness of a school-based intervention to the strategy used. To better examine the effectiveness of these school-based interventions randomized designs are thus necessary. Finally, short durations of the interventions may limit their effectiveness. Tuuri et al. [36] argue that the relatively short duration of their program - 12-weeks was insufficient to change children's outcomes. It is therefore recommended to test their intervention in the future, but with a longer duration.

2. Limitations derived from the experimental procedures used. Within such limitations, Wang et al. [40] highlight that their intervention was not applied at home, thus the resulting increases in FV consumption observed among some students concern only foods eaten during school hours, and cannot be generalized to foods consumed at home. None of the studies described here targeted the home food environment, so this limitation also affects them. Prelip et al. [45] highlight, in turn, that their intervention did not target the school food intervention, which may explain the lack of changes in children's $V$ consumption. Future studies should combine both home and school food environments. Thatchildren might have had insufficient opportunities to learn to like the flavor of the $\mathrm{V}$ during the intervention that included only $4 \mathrm{~V}$ offerings, is another limitation hypothesized by Schindler et al. [46].
Hence, this hypothesis should be tested in the future. Olsen et al. [44], on their part, affirm that all participants received similar, but alternating servings of $\mathrm{V}$ at liking test days, thus leading to confounding between serving order and intervention group, which has to be avoided in future studies. Finally, Rohlfs Domínguez et al. [49] underline that they did not assess children's motivation (liking or preference) for the targeted stimuli, nor attentional focus during and after their intervention, and therefore endorse the need to assess these variables in the future, to determine why children eat more $\mathrm{V}$ under choice conditions.

3. Limitations affecting participant samples. The most common of this type of limitation concerns the limited generalization of the results due to the fact that participants were mostly of one ethnicity (i.e. white or black) or socioeconomic group (i.e. low-income families). This limitation affects the interventions by Tuuri, et al. [36], Swanson et al. [37], Parmer et al. [38], Lakkakula et al. [39], Lakkakula et al. [42], Olsen et al. [44], Prelip et al. [45], Cohen et al. [50], Perikou et al. [53], and Wengreen et al. [52]. Consequently, the effectiveness of these interventions should be examined in different ethnic and socioeconomic groups in the future. The second most common limitation of this type is related to the participant sample size. This was not as large as desirable in several studies, such as those by Parmer et al. [38], Lakkakula et al. [39], Hoffman et al. [43], Prelip et al. [45], and Cohen et al. [47]. Finally, previous experience of some schools with these interventions may have resulted in advantages over other schools in implementing the intervention, for example, in the study by Wang et al. [40]. Hence, this variable should be controlled in future school-based interventions.

4. Limitations concerning data collection. In some studies, questionnaires were used to collect information on children (i.e. Lakkakula et al. [39]); thus social desirability might have biased the results [39]. Moreover, in the study by Leines et al. [51], the survey used self-reported dichotomous questions, which limits children's provision of information. As Wang et al. [40] have argued, young children have difficulties in providing researchers with required information because of their still limited language capacities. For these reasons, development of methods of data collection adapted to children's age and language are warranted. In some studies (i.e. Wang et al. [40]; Perikkou et al. [50]), information on children's nutritional outcomes was collected only on working days, hence information should also be collected on weekends in 
future studies. Results reported by Olsen et al. [44] could have reflected peer influences and the fact that some children dropped the targeted items on the floor. Finally, Perikkou et al. [50] affirm that in their study parents reported information for their children, but they may not have known exactly what their children ate outside the school. Therefore, peer influences, parents' ignorance regarding what their children eat outside the school and data loss due to children's actions associated with dropping the targeted stimuli should be avoided or compensated in future school-based interventions. Ways to overcome these limitations are summarized in Table 5.

Table 5: Strategies for Overcoming the Research Limitations of School-Based Interventions Identified

1. Add at least one post-intervention follow-up assessment.

2. Add control groups.

3. Use randomized designs.

4. Apply the intervention during longer time intervals.

5. Include the home and school food environments.

6. Offer children a higher number of $\mathrm{V}$.

7. Assess children's motivation (liking or preference) for the targeted stimuli and attentional focus during and after the intervention.

8. Examine the effectiveness of these interventions in different ethnicities and socioeconomic groups.

9. Include larger participant samples.

10. Control schools' previous experience with interventions.

11. Use data-collection methods suited to children.

12. Collect information related to children's nutritional outcomes also in weekends.

13. Control peer influences on children's nutritional outcomes.

14. Avoid children's actions associated with dropping the targeted stimuli on the floor.

15. Avoid parents' ignorance regarding what do their children eat outside the school.

Based on this discussion, I propose several new working hypotheses (Table 6).

Table 6: New Hypotheses Derived from the Targeted School-Based Interventions for Future Research

1. The provision to children of nutritional and gardening education might increase their $\mathrm{F}$ selection, consumption and preferences.

2. Schools' previous experience with these interventions might distort children's post-intervention data related to their nutritional outcomes.

3. Application of evaluative conditioning under more appropriate experimental conditions might increase child $\mathrm{V}$ consumption.

4. Development of age- and F-specific strategies might encourage child $\mathrm{F}$ consumption.

5. Increasing the palatability of the FV served might increase children's preferences for FV.

6. A small number of $V$ offered might lead to insufficient opportunities to learn to like the flavour of $\mathrm{V}$.

\section{CONCLUDING REMARKS}

The present review aimed to identify school-based interventions executed during the compulsory education period that may be effective in increasing healthful nutritional outcomes in children, along with their associated limitations and implications for future research. Seventeen different school-based interventions that are effective in increasing children's nutritional outcomes during this period were identified. Taken as a whole, these school-based interventions vary according to the specific strategy used to promote healthy nutritional outcomes in children and evidence four types of limitations.

I recommend fifteen ways to overcome the limitations described above, and present six new hypotheses to be assessed in the future.

The principal contribution of this review is to enhance awareness within the scientific community of the need to conduct further research on strategies that promote children's healthy nutritional outcomes as well as to overcome research-related limitations, even if this is not possible currently.

Finally, the suggestions for the future presented here are probably not viable currently, but they may inspire other researchers to find solutions in the future for the obstacles that hinder viability of these suggestions currently.

\section{ACKNOWLEDGEMENTS}

This work was developed through the efforts from Dr. Richard $\mathrm{H}$ Porter in making interesting suggestions and refining the English language of the text.

\section{CONFLICT OF INTEREST}

There is no conflict of interest to declare.

\section{REFERENCES}

[1] World Health Organization (WHO) [Internet]. [Updated 2009 July 17; cited 2009 Jul 17]. Available from http://www.who.int/dietphysicalactivity/fruit/en/index.html.

[2] Aranceta J, Pérez-Rodrigo C, Serra-Majem L, Bellido D, de la Torre, ML, Formiguera $\mathrm{X}$, Moreno $\mathrm{B}$. Prevention of overweight and obesity: a Spanish approach. Public Health Nutr 2007; 10(10A): 1187-93. http://dx.doi.org/10.1017/S1368980007000699

[3] Van Duyn MAS, Pivonka E. Overview of the health benefits of fruit and vegetable consumption for the dietetics professional: selected literature. J Am Diet Assoc 2000; 100: 1511-1521. http://dx.doi.org/10.1016/S0002-8223(00)00420-X

[4] Maynard M, Gunnell D, Emmett P, Frankel S, Davey S. Fruit, vegetables, and antioxidants in childhood and risk of adult 
cancer: the Boyd Orr cohort. Journal Epidemiol Commun 2003; 57(3): 218-25.

http://dx.doi.org/10.1136/jech.57.3.218

[5] Mikkilä V, Räsänen L, Raitakari OT, Pietinen P, Viikari J. Longitudinal changes in diet from childhood into adulthood with respect to risk of cardiovascular diseases: the cardiovascular risk in young finns study. Eur J Clin Nutr 2004; 58(7): 1038-45.

http://dx.doi.org/10.1038/sj.ejcn.1601929

[6] Lorson BA, Melgar-Quinonez HR, Taylor Ch A. Correlates of fruit and vegetable intakes in US children. J Am Diet Assoc 2009; 109(3): 474-8. http://dx.doi.org/10.1016/j.jada.2008.11.022

[7] Yngve A, Wolf $\mathrm{A}$, Poortvliet $\mathrm{E}$, et al. Fruit and vegetable intake in a sample of 11-year-old children in 9 European countries: the pro children cross-sectional survey. Ann Nutr Metab 2005; 49(4): 236-45. http://dx.doi.org/10.1159/000087247

[8] Baxter SD, Thompson WO, Davis HC. Fourth-grade children's observed consumption of, and preferences for, school lunch foods. Nutr Res 2000; 20(3): 439-43. http://dx.doi.org/10.1016/S0271-5317(00)00136-6

[9] Jaramillo SJ, Yang SJ, Hughes SO, Fisher JO, Morales M, Nicklas TA. Interactive computerized fruit and vegetable preference measure for African-American and Hispanic preschoolers. J Nutr Educ Behav 2006; 38(6): 352-9. http://dx.doi.org/10.1016/j.jneb.2006.06.003

[10] Burguess-Champoux T, Marquart L, Vickers Z, Reicks M. Perceptions of children, parents, and teachers regarding whole-grain foods, and implications for a school-based intervention. J Nutr Educ Behav 2006; 38(4): 230-7. http://dx.doi.org/10.1016/j.jneb.2006.04.147

[11] Nicklaus S, Boggoi V, Chabanet C, Issanchou S. A prospective study of food preferences in childhood. Food Qual Prefer 2004; 15(7-8): 805-18.

http://dx.doi.org/10.1016/j.foodqual.2004.02.010

[12] Unusan N. University students' food preference and practice now and during childhood. Food Qual Prefer 2006; 17(5): 362-8.

http://dx.doi.org/10.1016/j.foodqual.2005.04.008

[13] Kimura A, Wada $Y$, et al. Eating habits in childhood relate to preference for traditional diets among young Japanese. Food Qual Prefer 2010; 21(7): 843-8.

http://dx.doi.org/10.1016/j.foodqual.2010.05.002

[14] Birch LL. Development of food preferences. Annu Rev Nutr 1999; 19: 41-62. http://dx.doi.org/10.1146/annurev.nutr.19.1.41

[15] Gibson EL, Wardle J, Watts CJ. Fruit and vegetable consumption, nutritional knowledge and beliefs in mothers and children. Appetite 1998; 31(2): 205-228.

http://dx.doi.org/10.1006/appe.1998.0180

[16] Mennella JA, Beauchamp GK. Flavor experiences during formula feeding are related to preferences during childhood. Early Hum Dev 2002; 68(2): 71-82. http://dx.doi.org/10.1016/S0378-3782(02)00008-7

[17] Mennella JA, Kennedy JM, Beauchamp GK. Vegetable acceptance by infants: effects of formula flavors. Early Hum Dev 2006; 82(7): 463-8.

http://dx.doi.org/10.1016/j.earlhumdev.2005.12.001

[18] Skinner JD, Carruth BR, Wendy B, Ziegler PJ. Children's food preferences: a longitudinal analysis. J Am Diet Assoc 2002; 102(11): 1638-1647.

http://dx.doi.org/10.1016/S0002-8223(02)90349-4

[19] Spanish Department of Education [Internet]. Madrid: Spanish Department of Education, Science and Sports [updated 2014 February 7; cited 2014 February 7]. Available from: http://www.mecd.gob.es/educacion-mecd/areas-educacion/ sistema-educativo/ensenanzas/educacion-primaria.html.
[20] Spanish Department of Education [Internet]. Madrid: Spanish Department of Education, Science and Sports [updated 2014 February 7; cited 2014 February 7]. Available from: http://www.mecd.gob.es/educacion-mecd/areas-educacion/ sistema-educativo/ensenanzas/educacion-infantil.html.

[21] Aranceta Bartrina J, Pérez Rodrigo C, Serra Majem L, Delgado Rubio A. Hábitos alimenarios de los alumnos usuarios de comedores españoles. Estudio "Dime cómo comes". Aten Prim 2004; 33(3): 131-9. http://dx.doi.org/10.1016/S0212-6567(04)79373-7

[22] Macairt J, Perros HG. A standardized frozen meals service for Irish schools. Eur J Oper Res 1982; 9(3): 248-256. http://dx.doi.org/10.1016/0377-2217(82)90032-7

[23] American Dietetic Association: Briggs M, Society for Nutrition Education: Safaii S, and American School Food Service Association: Beall DL. Position of the 218 American Dietetic Association, Society for Nutrition Education and American School Food Service Association-nutrition services: an essential component of comprehensive school health programs. J Am Diet Assoc 2003; 103(4): 505-14. http://dx.doi.org/10.1016/S0002-8223(03)00163-9

[24] Engström R, Carlsson-Kanyama A. Food losses in food service institutions. Examples from Sweden. Food Policy 2004; 29(3): 203-13. http://dx.doi.org/10.1016/j.foodpol.2004.03.004

[25] Sosa M, Hough G. Sensory acceptability of menus and sweet snacks among children and adults from low- and medium-income households in Argentina. Food Qual Pref 2006; 17(7-8): 590-7. http://dx.doi.org/10.1016/j.foodqual.2006.04.001

[26] Moore SN, Murphy S, Tapper K, Moore L. From policy to plate: barriers to implementing healthy eating policies in primary schools in Wales. Health Policy 2010; 94(3): 239-45. http://dx.doi.org/10.1016/j.healthpol.2009.10.001

[27] Briefel RR, Crepinsek MK, Canili Ch, Wilson A, Gleason PM. School food environments and practices affect dietary behaviors of US public school children. J Am Diet Assoc 2009; 109(Suppl 2): S91-107. http://dx.doi.org/10.1016/j.jada.2008.10.059

[28] Lytle LA. Measuring the food environment. Am J Prev Med 2009; 36(Suppl 4): S134-44.

[29] Krishnaswami J, Martinson M, Wakimoto P, Anglemeyer A. Community-engaged interventions on diet, activity, and weight outcomes in U.S. schools. A systematic review. Am J Prev Med 2012; 43(1): 81-91.

[30] Fung CH, Mclsaac JLD, Kuhle S, Kirk SFL, Veugelers PJ. The impact of a population-level school food and nutrition policy on dietary intake and body weights of Canadian children. Prev Med 2013; 57(6): 934-40. http://dx.doi.org/10.1016/j.ypmed.2013.07.016

[31] Berengueras-Pont MM. El sistema educativo de Alemania. Rev Asoc Inspec Edu Esp [Internet]. 2014 May [cited 2014 May 10]. Available from: http://www.adide.org/revista/index. php?option=com_content\&task=view\&id=266\&ltemid=71.

[32] USA Embassy-Buenos Aires. Estructura de la educación en EE.UU [Internet]. 2014 January [cited 2014 January 10] Available from: http://spanish.argentina.usembassy.gov/ media/pdfs/estructuraeducativa.pdf.

[33] Aghaei A, Afsar F, Nouri A. A comparison of the psychological characteristics of adolescence and drawing its profile according to parents and adolescents in Isfahan City (Iran). Procedia Soc Behav Sci 2012; 46: 2193-7. http://dx.doi.org/10.1016/j.sbspro.2012.05.453

[34] Padilla ML, Pfefferbaum A, Sullivan EV, Baker FC, Colrain IM. Dissociation of preparatory attention and response monitoring maturation during adolescence. Clin Neurophisiol 2013; 125(5): 962-70. http://dx.doi.org/10.1016/i.clinph.2013.10.012 
[35] Roseman MG, Riddell MC, Haynes JN. A content analysis of kindergarten-12th grade school-based nutrition interventions: taking advantage of past learning. J Educ Behav 2011; 43(1): 2-18.

http://dx.doi.org/10.1016/j.jneb.2010.07.009

[36] Tuuri, G, Zanovec, M, Silverman, L, Geaghan J, Solmon M, Holston D, Guarino A, Roy H, Murphy E. "Smart Bodies" school wellness program increased children's knowledge of healthy nutrition practices and self-efficacy to consume fruit and vegetables. Appetite 2009; 52(2): 445-51. http://dx.doi.org/10.1016/j.appet.2008.12.007

[37] Swanson, M, Branscum A, Nakayima. Promoting consumption of fruit in elementary school cafeterias. The effects os slicing apples and oranges. Appetite 2009; 53(3): 264-7.

http://dx.doi.org/10.1016/j.appet.2009.07.015

[38] Parmer SM, Salisbury-Glennon J, Shannon D, Struempler B. School gardens: an experimental learning approach for a nutrition education program to increase fruit and vegetable knowledge, preference and consumption among secondgrade students. J Nutr Educ Behav 2009; 41(3): 212-7. http://dx.doi.org/10.1016/j.jneb.2008.06.002

[39] Lakkakula A, Geaghan J, Zanovec M, Pierce S, Tuuri G. Repeated taste exposure increases liking for vegetables by low-income elementary school children. Appetite 2010; 55(2): 226-31.

http://dx.doi.org/10.1016/j.appet.2010.06.003

[40] Wang MC, Rauzon S, Studer N, Martin AC, Craig L, Merlo C, Fung K, Kursunoglu D, Shannguan M, Crawford P. Exposure to a comprehensive school intervention increases vegetable consumption. J Adolescent Health 2010; 47(1): 74-82. http://dx.doi.org/10.1016/j.jadohealth.2009.12.014

[41] Jones S, Spence M, Hardin S, Clemente N, Schoch A. Youth can! results of a pilot trial to improve the school food environment. J Nutr Educ Behav 2011; 43(4): 284-7. http://dx.doi.org/10.1016/j.jneb.2010.10.005

[42] Lakkakula A, Geaghan JP, Wong WP, Zanovec M, Pierce $\mathrm{SH}$, Tuuri G. A cafeteria-based tasting program increased liking of fruits and vegetables by lower, middle and upper elementary school-age children. Appetite 2011; 57(1): 299302.

http://dx.doi.org/10.1016/j.appet.2011.04.010

[43] Hoffman JA, Thompson DR, Franko DL, Power TJ, Leff SS, Stallings VA. Decaying behavioral effects in a randomized, multi-year fruit and vegetables intake intervention. Prev Med 2011; 52(5): 370-375.

http://dx.doi.org/10.1016/j.ypmed.2011.02.013
[44] Olsen A, Ritz Ch, Kraaij LW, Möller P. Children's liking and intake of vegetables: a school-based intervention study. Food Qual Prefer 2012; 23(2): 90-8. http://dx.doi.org/10.1016/i.foodqual.2011.10.004

[45] Prelip M, Kinsler J, Le Thai Ch, Toller Erausquin J, Slusser W. Evaluation of a school-based multicomponent nutrition education program to improve young children's fruit and vegetable consumption. J Nutr Educ Behav 2012; 44(4): 3108. http://dx.doi.org/10.1016/j.jneb.2011.10.005

[46] Schindler JM, Corbett D, Forestell CA. Assessing the effect of food exposure on children's identification and acceptance of fruit and vegetables. Eat Behav 2013; 14(1): 53-6. http://dx.doi.org/10.1016/j.eatbeh.2012.10.013

[47] Cohen JFW, Kraak, VI, Silvina F. The change study: a healthy-lifestyles intervention to improve rural children's diet quality. J Acad Nutr Diet 2013; 114(1): 48-53. http://dx.doi.org/10.1016/j.jand.2013.08.014

[48] Caraher M, Seeley A, Wu M, Lloyd S. When chefs adopt a school? An evaluation of a cooking intervention in English primary schools. Appetite 2013; 62: 50-9.

http://dx.doi.org/10.1016/j.appet.2012.11.007

[49] Rohlfs Domínguez P, Gámiz F, Gil M, Moreno H, Márquez Zamora R, Gallo M, De Brugada I. Providing choice increases children's vegetable intake. Food Qual Prefer 2013; 30(2): 108-13. http://dx.doi.org/10.1016/j.foodqual.2013.05.006

[50] Perikkou A, Gavrieli A, Kougioufa MM, Tzirkali M, Yannakoulia M. A novel approach for increasing fruit consumption in children. J Acad Nutr Diet 2013; 113(9): 1188-93. http://dx.doi.org/10.1016/j.jand.2013.05.024

[51] Leines DA, Gold A, Van Offelen S. Go wild with fruits and veggies! curriculum encourages children to eat more fruits and vegetables. J Nutr Educ Behav 2013; 46(1): 82-84. http://dx.doi.org/10.1016/j.jneb.2013.03.018

[52] Wengreen HJ, Madden GJ, Aguilar SS, Smits RR, Jones BA. Incentivizing children's fruit and vegetable consumption: Results of a US pilot-study of the Food Dudes program. J Nutr Educ Behav 2013; 45(1): 54-9. http://dx.doi.org/10.1016/j.jneb.2012.06.001

[53] Gast A, Gawronski B, De Houwer J. Evaluative conditioning: recent developments and future directions. Learn Motiv 2012; 43(3): 79-88. http://dx.doi.org/10.1016/j.Imot.2012.06.004 